\section{Femininities and masculinities in highly skilled migration: Peruvian graduates' narratives of employment transitions and binational marriages in Switzerland}

\begin{abstract}
Biographic research about migrant's gender identities grasps tendencies of normativity change chronologically and transnationally. Transition to employment stories of Peruvian graduates from Swiss universities evoke continuities and changes in femininities and masculinities from Peru to Switzerland. Binational marriages that mediate employment transition after graduation play an ambivalent role in the attainment of jobs commensurate to skills. Career, partner, and care are key elements of transgressing and reinforcing non/hegemonic masculinities and un/desirable femininities from super scientist women to failing male breadwinners. Feminization of highly skilled migration from Peru is linked to urban middle classes where femininities are increasingly based on career advancement. However, these professional-oriented femininities might be neutralized in favour of care-oriented femininities from family models in Switzerland. While Peruvian female graduates constructed an ideal of care/career integration predominantly, male counterparts emphasized the risk of career success at the expense of partnership.
\end{abstract}

Keywords: Highly skilled migration; binational marriages; gender norms; Switzerland; Peru.

\title{
Introduction
}

Peruvian migration represents an example of feminization of highly skilled migration. Among the 2.8 million of Peruvians ( $9 \%$ of the population in 2015) who left the country between 1990 and 2015, a large number of migrants were women. Peruvian women's international migration grew from 31\% between 1932 and 1950 to $57 \%$ in the period of 1991-2000, and then decreased to 53\% in 2015 (INEI, 2010, 2016b; Sanchez, 2012). Peruvians who migrated were highly educated between 1990 - 2015, and 21\% and 9\% declared being university students and professionals, respectively. During the same period, women represented $53 \%$ of professionals and $49 \%$ of students (INEI, 2016b). In the literature, although women's migration has been recently researched in relation to specific jobs and skills, such as care workers, the feminization of highly skilled migration has remained unexplored (Dumitru \& Marfouk, 2015). Drawing on a biographical approach, this article aims to fill this gap, with a special focus on the experiences of highly skilled Peruvian men and women in Switzerland. Highly skilled migration includes qualified foreigners who earn

\footnotetext{
${ }^{ \pm}$Romina Seminario, Graduate Assistant, Social Sciences Institute, Lausanne University, Switzerland. E-mail: rominaangie.seminarioluna@unil.ch.
} 


\section{Femininities and masculinities in bighly skilled migration}

Higher Education (HE) degrees in the host country, and subsequently embark on job hunting (Hawthorne, 2014). Aside from work-related legal paths, international student migration might be followed by binational marriage in order to settle in the host country (Fleischer, 2011). Foreign graduates' employment outcomes thus intertwine with family transitions such as partnership and parenthood (Geddie, 2013). Provided the gendered division of family caregiving, binational marriages can mediate highly skilled female and male migrants' labour market participation differently (Fleischer, 2011; Fresnoza-Flot, 2017). Researchers have paid little attention to professional and family-related masculinities and femininities amongst highly skilled migrants (Hibbins, 2005; Varrel, 2011). Here, I explore how Peruvian graduates from Swiss universities evoke gender norms while narrating their employment transitions, their partnership and childcare arrangements in Switzerland. Peruvian women's access to university education and the labour market in Peruvian urban middle class have an impact on the dissociation between femininity and maternity, on the growing importance given to professional projects (Fuller, 2001), as well as on the practice of delaying family formation (Cieza, 2016). When abroad, these women's career aspirations might clash with Swiss restrictive migration (Riaño, 2011) and neo-maternalistic care regimes (Giraud \& Lucas, 2009). In contrast with a binary vision that views home countries as sites of women's oppression and host countries as sites of women's emancipation, I found that the male breadwinner/female caregiver model persists in these highly skilled women's and men's transnational experiences between Peru and Switzerland.

The article is structured into six main sections. First, I briefly illustrate the literature about international students, highly skilled and family migration, and present my framework for studying gender norms in this context. Afterwards, I present the gendered employment and migration characteristics of Peru, as well as the Swiss care and migration regimes for non-EU foreigners. After describing my research methods, I analyse the meanings of femininities/masculinities in Peruvian graduates' narratives. Finally, I present some concluding remarks.

\section{Gender Norms in Binational Marriage: Mediation of Employment after Graduation}

Previous research focused on the spouse's role in academic mobility and international student migration (Bordoloi, 2015; Schaer, Dahinden, \& Toader, 2016), and on the impact of binational marriages on highly skilled non-EU women's careers (Raghuram, 2004; Riaño, 2011). International student migration has also received increased attention from various scholars (King \& Raghuram, 2013; Teichler, 2015), for instance regarding the legal situations and employment of foreign graduates (Hawthorne \& To, 2014; Mosneaga \& 
Winther, 2013; Suter \& Jandl, 2008). While interdependencies of family and professional trajectories for highly skilled migrants have been increasingly analysed (Geddie, 2013; Varrel, 2011), research on the role of binational marriages in foreign graduates' employment transitions in the host country is rather scarce (Fleischer, 2011). One reason is that family reunification procedures have usually been identified as an important route into legal settlement, especially for low-qualified foreign women, particularly in the care sector (Banfi \& Boccagni, 2011; Bonizzoni, 2015). Additionally, the theory of status exchange prevails to explain unequal qualifications between native and foreign spouses (Guetto \& Azzolini, 2015; Maffioli, Paterno, \& Gabrielli, 2014). Although research about binational marriage has highlighted its ambivalence in terms of constraints and resources (Fleischer, 2011; Fresnoza-Flot, 2017), issues of femininities and masculinities for highly skilled migrants have not been sufficiently explored (Adhikari, 2013; Batnitzky, McDowell, \& Dyer, 2009; Hibbins, 2005).

To explore femininities and masculinities in highly skilled migration, I compare the ways in which Peruvian graduates from Swiss universities narrate their transition to the labour market and their family experiences after graduation in Switzerland. Provided that gender norms can represent the symbolic dimensions (languages, discourses, representations) at the core of family and employment relations, I decided to focus on hierarchies within each gender, namely non/hegemonic masculinities and un/desirable femininities (Pearse \& Connell, 2015). Other sociocultural categories such as class and ethnicity intersect with gender norms to create dynamic and context-specific forms of categorizations (Erel, 2015). Therefore, I consider not only the class background of research participants, but also the effects of migration. Ecological (Alcalde, 2010), geometrical (Batnitzky et al., 2009), and inter-scalar (McIlwaine, 2010) perspectives on gender norms in migration can explain how particular notions of gender from countries of origin interact with local gender practices at the destination country. Furthermore, rather than considering "home" and "host countries" as opposed to each other, I view "there" and "here" as informing the decisions and practices of migrants synchronically (Grillo, 2007). Through this transnational approach, I consider the simultaneity and multi-locality of migrants' experiences, and focus on transformation and reinforcement of gender norms and their intersections with other categorizations (Batnitzky et al., 2009; Mahler \& Pessar, 2001; Pribilsky, 2012). In order to understand the temporality and spatiality of migrant women's and men's intersecting experiences, I propose to use a biographical approach (Giele, 2009). This approach focus on identity as processes of self/other positioning at the narrative level (Lykke, 2010). This approach also helps understanding the meanings attributed to events such as turning points and transitions. Besides considering migration as a turning point, I analyse here also employment and family transitions as critical biographical moments that can have an impact on 


\section{Femininities and masculinities in bighly skilled migration}

gender relations (Levy \& Widmer, 2013). My focus on migrants' narratives in transitional moments thus aims to understand how highly skilled Peruvian men and women might transgress hegemonic gender categories at times and participate in creating alternative ones.

\section{Peruvian Women's and Men's Access to Education, Employment, and Migration between Peru and Switzerland}

Peruvian women's access to university education has increased in the last decades, namely from $26 \%$ in 1960 to $45 \%$ in 2002 and to $49 \%$ in $2010^{1}$ (Garavito \& Carrillo, 2004; INEI, 2011). Although Peruvian women's participation in formal labour also increased from 59\% in 2000 to $63 \%$ in 2015 (INEI, 2016a), women's employment conditions have not ameliorated homogeneously. ${ }^{2}$ Peruvian women earned $70 \%$ of their male counterparts' salaries regardless of education level in 2015 (INEI, 2016a). As shown before, the feminization of Peruvian migration is highly skilled. Unsurprisingly, this trend in Peruvian migration also shows important urban and upper social class concentration (Sanchez, 2012, p. 85). Consequently, Peruvian women's access to education and migration affects gender norms in urban middle classes predominantly. Although urban middle class women declared the importance of professional success before motherhood, they plan to delay childbirth until graduation and opt out of employment during the first years of motherhood (Cieza, 2016; Fuller, 2001). Although fatherhood is still a central feature of masculinity, urban middle class men value not only the breadwinner role but also a caregiving one (Fuller, 2000). Peruvian university students and professional migrants adapt these gender normativity changes in Peru to gender and migration dynamics at the destination country.

The Swiss care and migration regimes particularly influence the feminization of highly skilled migration from Peru. ${ }^{3}$ Firstly, the Swiss care regime has been labeled as neo-maternalist, based on a male breadwinner/female caregiver family model (Baghdadi, 2010; Giraud \& Lucas, 2009; Giudici \& Gauthier, 2009). When considering the presence of small children, it is possible to observe the increase of gender differences: only $9.6 \%$ of couples had two spouses working full time in 2015 (FSO, 2016b). Secondly, the Swiss migration regime composed of the Federal Act on Foreign Nationals of 2008 highly inhibits the entrance and settlement of citizens from non-EU countries. Notably, student

\footnotetext{
${ }^{1}$ However, private universities hosted more women (65\%) than public universities (35\%) in 2010 (INEI, 2011). Yearly fees can go up to 3,000 USD (Rodríguez, 2009).

2 The Peruvian labour market is predominantly informal: a national rate of $75 \%$ that diminishes to $70 \%$ for women in urban areas but goes up to $97 \%$ for those in rural areas (INEI, 2016a).

${ }^{3}$ Although Switzerland hosted only $0.8 \%$ of Peruvians abroad in 2015 (INEI, 2016b), Peru's National Office of Electoral Processes reported 6,482 registered voters in Switzerland, while the Swiss National Office of Statistics counted only 2,898 Peruvian citizens (FSO, 2016a).
} 
permits ${ }^{4}$ are an expensive and time-consuming route into the country for nonEU citizens (Guissé \& Bolzman, 2015). Up until 2011, non-EU foreign students were required to leave the country immediately after graduation. Since then, a six-month "job search extension" permit for students has been introduced (State Secretariat for Migration, 2011). However, to recruit a non-EU foreign graduate, employers are required to attest that there is not any available Swiss or EU citizen for the job (The Federal Council, 2005). Given the uncertainties surrounding the transition from Swiss HE institutions to the labour market, graduates from non-EU countries who wish to remain in Switzerland are likely to consider family reunification measures such as binational marriages, ${ }^{5}$ which are often seen as more immediately accessible. However, it has been argued that the access of foreign spouses to settlement rights is conditioned on conformity to the family model in the Swiss care regime (Riaño \& Baghdadi, 2007).

\section{Methodology}

The data presented here were collected during the course of my $\mathrm{PhD}$ research and are based on a group of 19 Peruvians ( 9 women and 10 men) who had studied at a Swiss HE institution and were living in Switzerland at the time of the interview 6 (Table 1). Peruvian nationality was the main selection criterion, and those with dual nationality were also included. I carried out biographical interviews in Spanish using the LIVES life calendar (Morselli et al., 2013) 7 to collect systematic information about the important events in the participants' professional and family trajectories, as well as their own understanding of their transitions to the labour market. Contact with interviewees was established through personal networks and migrant associations using a "snowball" technique in order to reach a study population that was as diverse as possible in terms of gender, age, education, employment, and family situations. Although my position as a Peruvian woman from a privileged class and ethnic background working at a Swiss university eased the first contact with the interviewees, during the interview, gender, class, and race categorizations were negotiated.

\footnotetext{
${ }^{4}$ In $2015-2016,24.9 \%$ of Swiss HE students were "foreigners" in the sense that they had obtained their secondary school diploma outside of Switzerland, as compared to just 13.1\% of students in 1990-1991 (FSO, 2017b).

${ }^{5}$ In $2014,36 \%$ of marriages were composed of one foreign spouse, and approximately $11 \%$ of foreigners married to Swiss citizens were from South America (FSO, 2016b).

${ }^{6}$ Twelve interviewees ( 5 men and 7 women) had a Swiss spouse, one woman had a European Union spouse, and two men had a Peruvian spouse. Four interviewees ( 3 men and 1 woman) were single with no children at the time of the interview.

${ }^{7}$ A life calendar is defined as "a two-way grid, with the temporal dimension on the one side, and different life domains on the other. Respondents are asked to report events for each life domain, relating them to what happened across other domains or in references to time landmarks. While filling in this calendar, respondents can visualize their life trajectory, linking what happened to when, where and for how long it happened" (Morselli et al., 2013, p. 3).
} 
90 Femininities and masculinities in highly skilled migration

Table 1. Interviewee Profiles

\begin{tabular}{|c|c|c|c|c|c|}
\hline $\begin{array}{c}\text { Pseudo } \\
\text { nyms }\end{array}$ & $\begin{array}{c}\text { Initial field } \\
\text { of study }\end{array}$ & $\begin{array}{c}\text { Work } \\
\text { experience } \\
\text { before } \\
\text { migration }\end{array}$ & $\begin{array}{c}\text { Age at / } \\
\text { year of } \\
\text { migratio } \\
n\end{array}$ & $\begin{array}{l}\text { Migration } \\
\text { type }\end{array}$ & $\begin{array}{c}\text { Field of } \\
\text { Swiss } \\
\text { degree }\end{array}$ \\
\hline Alfonso & Engineering & Sales & $18 / 1995$ & Family & Engineering \\
\hline Samuel & Architecture & Architect & $38 / 2007$ & Student & Engineering \\
\hline Clotilde & Linguistics & Teacher & $24 / 1992$ & $\begin{array}{c}\text { Swiss } \\
\text { passport }\end{array}$ & Linguistics \\
\hline Carlos & Environment & $\begin{array}{c}\text { Environmentali } \\
\text { st }\end{array}$ & $25 / 2011$ & Student & Engineering \\
\hline Denis & Engineering & Engineer & $26 / 2011$ & Student & Engineering \\
\hline Coco & Physics & Researcher & $29 / 2008$ & Student & Engineering \\
\hline Miguel & Law & Lawyer & $28 / 1990$ & Student & $\begin{array}{l}\text { Business } \\
\text { studies }\end{array}$ \\
\hline Ernesto & Engineering & Engineer & $26 / 2008$ & Student & Engineering \\
\hline Nuria & Social work & Social worker & $27 / 1997$ & Student & Social work \\
\hline Concha & Medicine & Doctor & $37 / 2010$ & Marriage & Medicine \\
\hline Lola & Administration & Secretary & $26 / 1990$ & Student & Sociology \\
\hline $\begin{array}{l}\text { Merced } \\
\text { es }\end{array}$ & Translation & None & $20 / 1981$ & Student & Linguistics \\
\hline Juana & None & Secretary & $29 / 1990$ & Student & Sociology \\
\hline Rosa & Journalism & Journalist & $28 / 1990$ & Student & Sociology \\
\hline Felipe & Anthropology & Anthropologist & $31 / 2012$ & $\begin{array}{c}\text { Swiss } \\
\text { passport }\end{array}$ & Anthropology \\
\hline Clara & Engineering & Sales & $22 / 1996$ & $\begin{array}{c}\text { Undocument } \\
\text { ed }\end{array}$ & Humanities \\
\hline Ivan & $\begin{array}{c}\text { Law } \\
\text { enforcement }\end{array}$ & Police officer & $30 / 1988$ & Student & Law \\
\hline Claudio & Engineering & Engineer & $41 / 2008$ & Marriage & Engineering \\
\hline Luz & Economics & Sales & $29 / 1986$ & Marriage & Economy \\
\hline
\end{tabular}

I adopted a multidimensional and narrative analysis of life histories (FischerRosenthal, 2000; Levy \& Widmer, 2013). I considered interactions between parallel trajectories and processes of self-representation. Although I used NVivo software to analyse all interviews thematically, I present only extracts of the main narrative patterns found in after-graduation accounts. In particular, binational marriage as a legal outlet was omnipresent in Peruvian graduates' narrations of education to employment transitions in Switzerland, like exemplified by the following extract from the interview with Nuria ${ }^{8}$, a female graduate in social sciences: "I didn't even think about that [switching from student to work permit]. It was not even imaginable. I got married and that changed everything." Family formation in the host country thus triggered negotiations about care and career with ambivalent results: binational marriage either enables or constrains the search for employment commensurate to one's skills.

${ }^{8}$ I used pseudonyms instead of participants' real names.

ww.migrationletters.com 
Femininities and Masculinities in Peruvian Graduates' Narratives of Transitions

These highly skilled men and women narrated their after-graduation experiences by criticizing, adapting, and transforming gender norms between Peru and Switzerland. Peruvian male graduates emphasized processes of racialization (e.g., restricted laws and stereotypes against Latin Americans) that hindered employment and breadwinner roles. Peruvian female graduates described dissonance between caregiver roles reinforced in Switzerland and career advancement goals already established in Peru. In what follows, I illustrate the multiple ways in which aspects of femininities and masculinities are mobilized, by discussing the three most common features characterizing the participant's narratives of employment and family transitions: "super scientist women," "unbalanced femininities," and "non-hegemonic masculinities."

\section{Does the Super Scientist Woman Exist? Excelling in Care and Career}

When Peruvian women narrated their struggles to achieve career advancement after graduation and marriage, perceptions and practices about family caregiving emerged in two forms: balance or imbalance. Instead of replacing the woman's caregiver role with professional goals, the first one reflects the "superwoman" image of excelling in career and care simultaneously. The narratives included perceptions and practices of a having-it-all femininity. Concha, an $\mathrm{MD} / \mathrm{PhD}$ doing a postdoc, explained it as follows:

I never thought that I would have a strong maternal side. For me, it was important to spend quality time with my daughter. ... While working on my $\mathrm{PhD}$ research, I didn't sleep in order to feed her timely and always play with her. ... Unlike Switzerland, academia in the USA is highly competitive: I had to work 13-12 hours a day to publish high-quality articles. My husband had already left to do his post-doc in Switzerland. . .. It was a terrible year but the most productive one. When my post-doc supervisor asked how did I do it? I told him that it was teamwork thanks to my former supervisor's flexibility and my brother's help. But I got an ulcer. So, I told him that there isn't a perfect recipe or super woman because something always ends up paying. I published excellent papers but I got sick. ... In Switzerland, the problem was [my daughter] transition from nursery to school due to schedule. ... Thanks to my supervisor's flexibility, unlike the strict one my husband had, my daughter enjoyed her mother 100\%. I was like a stay-at-home mom. I went to work at 5am, picked her up in the afternoon and took her to different courses, and my publications were also excellent.

Ideals of career advancement for Peruvian women with a middle-class background are perceived as feasible but contingent to host countries' conditions to fulfill traditional gender roles. This new validation has 


\section{Femininities and masculinities in highly skilled migration}

contradictions. When taking into account also employment conditions, cultural norms, as well as national care regimes, rewards of super femininity come at the expense of other life domains (e.g., health). Instead of giving up career for motherhood, this resolution of the care/career conundrum transgresses oppositional femininities-family or work-in favor of more encompassing ones. Other forms of resolution put forward the imbalance between care and career.

\section{Opting Out or Outshining in the Labour Market}

For other Peruvian female graduates, imbalances between care and career were expressed in two ways: opting out of the labour market to focus on family caregiving or outlasting the spouse in the labour market to agree on shared family caregiving. While reinforcing a female caregiver role, the former points out particular family and institutional limitations for migrant women's career/care projects without questioning a couple's gendered distribution. In contrast, the latter does not transgress the female caregiver role but promotes an exceptional distribution within the couple. For instance, Juana, who graduated from social sciences and does volunteering, struggled to define herself as a wife who did not work but invested her time in hobbies; also Nuria, who graduated from social sciences and works in an HE institution, highlighted the "peculiar" caregiving arrangement with her husband:

Let's say that not working would have been less annoying if people didn't see you in a special way. Because you are always categorized based on what you do instead of what you are. Of course, work is a mode of valorisation but it is also a way of not talking about you. ... A woman once even asked me: "What can you talk about with your husband?" Excuse me! If you knew that I could talk about a million of things: the book I just read, the play I just saw.

Our family is rather peculiar because my husband has an irregular job and I have a stable one. I have always worked at least $80 \%$ and he has jobs of $20 \%$ or $50 \%$ sporadically. He is a chemist and works by projects. Consequently, this [situation] allows him to stay at home and take care of the children more than me. When I was doing my $\mathrm{PhD}$, he worked more hours. But this changed since I started [to work] at the university and our children were born. ... Despite an interesting job offer for him in Spain, we decided to stay in Switzerland. I had a permanent job with good prospects. My qualifications are valorised and salaries are higher here.

Career advancement becomes ambivalent as a troubling void or exceptional achievement in these narratives. However, narratives about opting out of the labour market not only accentuated family caregiving but also created validation 
for women beyond the family: volunteering and hobbies. Those alternatives also correspond to femininities amongst privileged classes (Taylor, 2005). In contrast with an unquestionable profession-oriented masculinity, women's narratives of successful careers go together with explanations for family caregiving delegation. Indeed, the main reason is outshining the husband in the labour market. Also, narratives of career advancement highlight its contingency on the actual amount of family caregiving. Peruvian female graduates without children felt compelled to succeed in their careers. Transgressions of family caregiving femininity show how professional success represents not only a goal but also a supplement for family-related ideals. Ironically, this might reinforce caregiving and/or super scientist femininities as superior forms. Instead of recalling traditional femininities, when ideals of career advancement from Peru do not seem to fit in family caregiving in Switzerland, Peruvian women's identity work displays alternatives based on classed femininities: compensatory volunteering and outstanding professional status.

\section{Failing Breadwinners, Caring Fathers, and Workaholic Ex-Husbands: Signs of New Masculinities?}

Peruvian male graduates' narratives of transitions from university education to employment, emphasized success or failure in accessing the Swiss labour market. Career advancement remains the most important source of validation in their identity work. By positioning themselves as migrants, Peruvian male graduates narrated processes of racialization that hindered their employment outcomes. However, they also emphasized gendered professional advantages to overcome these barriers. For instance, Ernesto explained the advantage of being an engineer:

I wouldn't say [finding a job after graduation] is easy. I would say that it is possible for $70 \%-80 \%$ [of cases] when you have a university degree in technical fields of study. Those fields have more demand and language is less important. I met a Chilean female lawyer that had to leave after graduation because she didn't find a job.... I have never seen a Peruvian in a technical career that had to leave due to unsuccessful job hunting. They find a [paid] PhD position or employment. It might take some time but they settled here finally.

Family caregiving is also described as supplementing breadwinner shortcomings. Transgression of the male breadwinner/female caregiver family model fosters recognition of caregiving masculinities. Ivan, a law graduate, hesitantly explained his pride of being more involved than his Swiss wife in caregiving, due to nationality-based disadvantages:

I couldn't work due to my permit. I said to police officers: "I had studied here and have a bachelor's degree, and I can't even deliver newspapers? 


\section{Femininities and masculinities in highly skilled migration}

You are sabotaging me but I am married to a woman and I have a child, both are Swiss citizens.". . . At that moment, full-time childcare was expensive and I told my wife that I would take care of our child and study part-time to get my master's degree. My wife was working $100 \%$, so she provided the main household income... Swiss people have good jobs and earn adequate salaries. I assumed domestic chores that represented a new experience for me because in Lima I didn't even see my child. I worked and travelled a lot and the maid did everything. So, I came here and started to change diapers, take him to kindergarten, sport and music lessons. I don't regret it. I sacrificed a lot professionally.

Although career advancement is central, it might not guarantee an unquestionable masculinity. Indeed, other dimensions of manhood are important, such as partnership. Overemphasis on employment at the expense of couples' well-being represented a failure. For instance, Miguel, a law and business graduate, regretted the ways in which work cultures in finances are at odds with partnership:

I love my work and my family but I am divorcing. It is a "failure."... [The cause of my divorce] was work. She constantly complained that my work took me too much time. It is true that I returned home at night and ate with the children and then I started to work. ... I was reading for an article or book to write. I might have done something wrong but I don't think so. ... When you go higher, you have less time for your partner.

Binational marriages after graduation are also ambivalent in terms of masculinities in employment transition stories. At intersections with racialization, caregiving masculinity evokes a lack of professional success but also illustrates new validations for Peruvian male graduates. In addition, excelling breadwinner masculinities challenge wife/husband relations as another important aspect of male identities.

\section{Conclusions}

The focus on the feminization of highly skilled migration proposed in this paper showed that transnational gender and family dynamics for these migrants can involve multiple and contradictory trends (Erel, 2015). Taking into account other categorizations (e.g., class), trends of normativity change do not follow one direction (e.g., from home to host countries) but multiple ones. Indeed, simultaneity and multi-locality of references influence intersectional experiences in migration (Fresnoza-Flot \& Shinozaki, 2017). Against the tradition/modernity dichotomy between home and host country, Peruvian graduates' narratives evoke continuities and changes in femininities and masculinities from Peru to Switzerland. Binational marriage mediates 
employment transition after graduation as a legal outlet for job-hunting, but also as a site of caregiving negotiations. For these highly skilled migrants, it thus plays an ambivalent role in professional advancement. Career, partner, and care are key elements of transgressing and reinforcing non/hegemonic masculinities and un/desirable femininities. Whereas Peruvian men's narratives stressed contradictions between career, partner, and care, Peruvian women predominantly constructed an ideal of integration of these aspects.

Thanks to a biographical approach, this article suggests that the feminization of highly skilled migration from Peru is linked to the urban middle class femininities based on career advancement increasingly. However, these profession-oriented femininities might be neutralized in favor of care-oriented femininities from family models in Switzerland. In addition, growing barriers to achieve a male breadwinner role transnationally do not necessarily translate into widespread caregiving masculinity. However, migrant women and men do not automatically recall traditional gender norms, but evoke alternative femininities and masculinities in relation to class and nationality: from super scientist women to caring fathers.

These findings encourage broadening the analytical focus of intersectional experiences in migration. This paper, in particular, invites for further analytical comparisons between experiences of migrant men and women with different skill levels, and their experiences of family relations and gender roles transnationally.

\section{References}

Adhikari, R. (2013). Empowered Wives and Frustrated Husbands: Nursing, Gender and Migrant Nepali in the UK. International Migration, 51(6), 168-179. http:/ / doi.org/10.1111/imig.12107

Alcalde, M. C. (2010). Violence across borders: Familism, hegemonic masculinity, and self-sacrificing femininity in the lives of Mexican and Peruvian migrants. Latino Studies, 8(1), 48-68. http://doi.org/10.1057/1st.2009.44

Baghdadi, N. (2010). Care-Work arrangements of parents in the context of family policies and extra-familial childcare provision in Switzerland (Research reports No. 3\&4). Geneva.

Batnitzky, A., McDowell, L., \& Dyer, S. (2009). Flexible and Strategic Masculinities: The Working Lives and Gendered Identities of Male Migrants in London. Journal of Ethnic and Migration Studies, 35(8), 1275-1293. http://doi.org/10.1080/ 13691830903123088

Bordoloi, S. D. (2015). 'I Am Standing Still': The Impact of Immigration Regulations on the Career Aspirations of Wives of International Students in the USA. Journal of International Migration and Integration, 16, 607-624. http://doi.org/10.1007/s12134014-0354-4

Cieza, K. (2016). Representaciones Sociales de la Maternidad y los Significados que le asignan las Mujeres Jóvenes Universitarias de Estratos Medios Bajos de Lima Metropolitana en la Construcción de las Feminidades e Identidades Femeninas. PUCP. 


\section{Femininities and masculinities in highly skilled migration}

Dumitru, S., \& Marfouk, A. (2015). Existe-t-il une féminisation de la migration internationale? Féminisations de la migration qualifiée et invisibilité des diplômes. Hommes et Migrations, 1311(2), 31-41.

Erel, U. (2015). Thinking Migrant Capitals Intersectionality: Using a Biographical Approach. In Migrant Capital. Networks, Identities and Strategies (pp. 18-32). London: Palgrave Macmillan.

Fischer-Rosenthal, W. (2000). Biographical work and biographical structuring in present-day societies. In The Turn to Biographical Methods in Social Science. Comparative issues and exemples (pp. 109-123). London: Routledge.

Fleischer, A. (2011). Marriage across space and time among male migrants from Camerron to Germany. In Gender, generations and the family in international migration (pp. 243-264). Amsterdam: IMISCOE/Amsterdam University.

Fresnoza-Flot, A. (2017). Gender-and social class-based transnationalism of migrant Filipinas in binational unions. Journal of Ethnic and Migration Studies, (March). http:/ /doi.org/10.1080/1369183X.2016.1274562

Fresnoza-Flot, A., \& Shinozaki, K. (2017). Transnational perspectives on intersecting experiences: gender, social class and generation among Southeast Asian migrants and their families. Journal of Ethnic and Migration Studies, 43(6), 867-884. http://doi.org/10.1080/1369183X.2016.1274001

FSO. (2016a). Population résidante selon Année, Type de population, Sexe et Nationalité (continent). Retrieved 27 June 2016, from https://www.pxweb.bfs. admin.ch/Table.aspx?layout $=$ tableViewLayout2\&px_tableid $=$ px-x-0103010000 _203\%255cpx-x-0103010000_203.px\&px_language =fr\&px_type =PX\&px_db= px-x-0103010000_203\&rxid=14d82763-4354-4bbb-986e-f0da97200b61

FSO. (2016b). Taux d'activité professionnelle. Retrieved 27 June 2016, from http://www.bfs.admin.ch/bfs/portal/fr/index/themen/20/05/blank/key/erwer bstaetigkeit/erwerbsbeteiligung.html

Fuller, N. (2000). Significados y prácticas de paternidad entre varones urbanos del Perú. In N. Fuller (Ed.), Paternidades en América Latina (pp. 35-89). Lima: PUCP Fondo Editoria.

Fuller, N. (2001). Maternidad e identidad femenina: relato de sus desencuentros. In S. Donas Burak (Ed.), Adolescencia y juventud en America Latina (pp. 225-242). Cartago: Libro Universitario Regional. http:/ / doi.org/10.4067/S0718-22362004000200004

Garavito, C., \& Carrillo, M. (2004). Feminización de la Matrícula de Educacion Superior y Mercado de Trabajo en el Perú: 1978-2003. Lima.

Geddie, K. (2013). The transnational ties that bind: Relationship science and engineering research students relationship considerations for graduating international students. Population, Space and Place, 19(November 2012), 196-208. http://doi.org/10.1002/psp

Giele, J. (2009). Life Stories to Understand Diversity. Variations by Class, Race and Gender. In The Craft of the lifecourse Research (pp. 236-257). New York: The Guilford Press.

Giraud, O., \& Lucas, B. (2009). Le renouveau des régimes de genre en Allemagne et en Suisse: bonjour 'néo maternalisme'? Cabiers Du Genre, 46(1), 17-46. http:/ / doi.org/10.3917/cdge.046.0017

Giudici, F., \& Gauthier, J. (2009). Différentiation des trajectoires professionnelles liées à la transition à la parentalité en Suisse. Swiss Journal of Sociology, 35(2), 253-278. 
Grillo, R. (2007). Betwixt and Between: Trajectories and Projects of Transmigration. Journal of Ethnic and Migration Studies, 33(2), 199-217. http://doi.org/10.1080/ 13691830601154138

Guetto, R., \& Azzolini, D. (2015). An Empirical Study of Status Exchange through Migrant / Native Marriages in Italy, 41(13), 2149-2172. http://doi.org/10.1080/ 1369183X.2015.1037725

Hawthorne, L. (2014). Indian students and the evolution of the study-migration pathway in Australia. International Migration, 52(2), 3-19. http://doi.org/10.1111/ imig. 12110

Hawthorne, L., \& To, A. (2014). Australian employer response to the study-migration pathway: The quantitative evidence 2007-2011. International Migration, 52(3), 99-115. http://doi.org/10.1111/imig.12154

Hibbins, R. (2005). Migration and gender identity among Chinese skilled male migrants to Australia. Geoforum, 36(2 SPEC. ISS.), 167-180. http://doi.org/10.1016/ j.geoforum.2003.10.003

INEI. (2010). Perú: Estadísticas de la Emigración Internaciona de Peruanos e Inmigración de Extranjeros 1990-2009. Lima.

INEI. (2011). II Censo Nacional Universitario 2010. Lima.

INEI. (2016a). Perú: Brechas de Género 2016. Avances hacia la igualdad de mujeres y hombres. Lima.

INEI. (2016b). Perú: Estadísticas de la Emigración Internacional de Peruanos e Inmigración de Extranjeros, 1990-2013. Lima: INEI, MIGRACIONES, OIM.

King, R., \& Raghuram, P. (2013). International Student Migration: Mapping the Field and New Research Agendas. Population, Space and Place, 19(2), 127-137. http://doi.org/10.1002/psp.1746

Levy, R., \& Widmer, E. D. (2013). Gendered life courses between standardization and individualization. A European approach applied to Switzerland. Zurich/Berlin: LIT.

Lykke, N. (2010). Theorizing intersectionalities. Genealogies and Blind Spots. In Feminist Studies. A Guide to Intersectional Theory, Methodology and Writing. (pp. 67-86). New York: Routledge.

Maffioli, D., Paterno, A., \& Gabrielli, G. (2014). International married and unmarried unions in italy: Criteria of mate selection. International Migration, 52(3), 160-176. http://doi.org/10.1111/imig.12049

Mahler, S. J., \& Pessar, P. R. (2001). Gendered Geographies of Power: Analyzing Gender Across Transnational Spaces. Identities, 7(4), 441-459. http://doi.org/ 10.1080/1070289X.2001.9962675

McIlwaine, C. (2010). Migrant machismos: exploring gender ideologies and practices among Latin American migrants in London from a multi-scalar perspective. Gender, Place \& Culture, 17(3), 281-300. http://doi.org/10.1080/09663691003737579

Morselli, D., Le, J., Brändle, K., Mugnari, E., Roberts, C., Bernardi, L., ... Kühr, J. (2013). Assessing the performance of the Swiss Panel LIVES Calendar: Evidence from a pilot study Authors (LIVES Working Papers No. 28). Lausanne.

Mosneaga, A., \& Winther, L. (2013). Emerging Talents? International Students Before and After Their Career Start in Denmark. Population, Space and Place, 19(2), 181-195. http://doi.org/10.1002/psp.1750 


\section{Femininities and masculinities in highly skilled migration}

Pearse, R., \& Connell, R. (2015). Gender Norms and the Economy: Insights from Social Research. Feminist Economics, 1-24. http://doi.org/10.1080/ 13545701. 2015.1078485

Pribilsky, J. (2012). Consumption Dilemmas: Tracking Masculinity, Money and Transnational Fatherhood Between the Ecuadorian Andes and New York City. Journal of Ethnic and Migration Studies, 38(2), 323-343. http://doi.org/10.1080/ 1369183X.2012.646429

Raghuram, P. (2004). The difference that skills make: gender, family migration strategies and regulated labour markets. Journal of Ethnic and Migration Studies, 30(2), 303-321. http://doi.org/10.1080/1369183042000200713

Riaño, Y. (2011). 'He's the Swiss citizen, I'm the foreign spouse': Binational marriages and the impact of family-related migration policies on gender relations. In Gender, generations and the family in international migration (pp. 265-282). Amsterdam: Amsterdam University Press.

Sanchez, A. (2012). Perfil Migratorio del Perú 2012. Lima: Organización Internacional para las Migraciones (OIM).

Schaer, M., Dahinden, J., \& Toader, A. (2016). Transnational mobility among earlycareer academics: gendered aspects of negotiations and arrangements within heterosexual couples. Journal of Ethnic and Migration Studies, 43(8), 17. http://doi.org/10.1080/1369183X.2017.1300254

Suter, B., \& Jandl, M. (2008). Train and retain: National and regional policies to promote the settlement of foreign graduates in knowledge economies. Journal of International Migration and Integration, 9(4), 401-418. http://doi.org/10.1007/s12134008-0072-x

Taylor, R. F. (2005). Rethinking voluntary work. Sociological Review, 53(SUPPL. 2), 119 135. http://doi.org/10.1111/j.1467-954X.2005.00576.x

Teichler, U. (2015). Academic Mobility and Migration: What We Know and What We Do Not Know. European Review, 23(S1), S6-S37. http://doi.org/10.1017/ S1062798714000787

Varrel, A. (2011). Gender and intergenerational issues in the circulation of highly skilled migrants: The case of Indian IT professionals. In Gender, generations and the family in international migration (pp. 141-161). Amsterdam: University of Amsterdam Press. 